\title{
Influence of Tall Fescue Epichlö̈ Endophytes on Rhizosphere Soil Microbiome
}

\author{
Kishan Mahmud ${ }^{1}$, Kendall Lee ${ }^{2}$, Nicholas S. Hill ${ }^{3}$, Anaas Mergoum ${ }^{4}$ and Ali Missaoui ${ }^{1,2,3, *(D)}$ \\ 1 Center for Applied Genetic Technologies, University of Georgia, Athens, GA 30602, USA; \\ kishan.mahmud25@uga.edu \\ 2 Institute of Plant Breeding, Genetics and Genomics, University of Georgia, Athens, GA 30602, USA; \\ kendall.lee94@uga.edu \\ 3 Department of Crop and Soil Sciences, University of Georgia, Athens, GA 30602, USA; nhill@uga.edu \\ 4 Department of Internal Medicine, School of Medicine and Health Sciences, University of North Dakota, \\ Grand Forks, ND 58102, USA; anaas.mergoum@und.edu \\ * Correspondence: cssamm@uga.edu
}

check for updates

Citation: Mahmud, K.; Lee, K.; Hill, N.S.; Mergoum, A.; Missaoui, A. Influence of Tall Fescue Epichloë Endophytes on Rhizosphere Soil Microbiome. Microorganisms 2021, 9 , 1843. https://doi.org/10.3390/ microorganisms 9091843

Academic Editor: Volker Brozel

Received: 24 June 2021

Accepted: 28 August 2021

Published: 31 August 2021

Publisher's Note: MDPI stays neutral with regard to jurisdictional claims in published maps and institutional affiliations.

Copyright: (c) 2021 by the authors. Licensee MDPI, Basel, Switzerland. This article is an open access article distributed under the terms and conditions of the Creative Commons Attribution (CC BY) license (https:/ / creativecommons.org/licenses/by/ $4.0 /)$.

\begin{abstract}
Tall fescue (Lolium arundinaceum (Schreb.) S.J. Darbyshire) often forms a symbiotic relationship with fungal endophytes (Epichloë coenophiala), which provides increased plant performance and greater tolerance to environmental stress compared to endophyte-free tall fescue. Whether this enhanced performance of tall fescue exclusively results from the grass-fungus symbiosis, or this symbiosis additionally results in the recruitment of soil microbes in the rhizosphere that in turn promote plant growth, remain a question. We investigated the soil bacterial and fungal community composition in iron-rich soil in the southeastern USA, and possible community shifts in soil microbial populations based on endophyte infection in tall fescue by analyzing the 16s rRNA gene and ITS specific region. Our data revealed that plant-available phosphorus $(\mathrm{P})$ was significantly $(p<0.05)$ influenced by endophyte infection in tall fescue. While the prominent soil bacterial phyla were similar, a clear fungal community shift was observed between endophyte-infected (E+) and endophyte-free (E-) tall fescue soil at the phylum level. Moreover, compared to E- soil, E+ soil showed a greater fungal diversity at the genus level. Our results, thus, indicate a possible three-way interaction between tall fescue, fungal endophyte, and soil fungal communities resulting in improved tall fescue performance.
\end{abstract}

Keywords: tall fescue; endophyte; soil; rhizosphere microbiome; plant-soil interaction

\section{Introduction}

Grasses cover almost $20 \%$ of the total land area on the planet [1] and are widely distributed ecosystems [2]. They offer important ecosystem services, such as providing forage for livestock [3], soil carbon sequestration [4], improved runoff quality [5], erosion control, climate regulation [6], and resistance to invasive species [7]. Many grass species are known to form symbiotic relationships with fungal endophytes [8] that led to eventual plant colonization of terrestrial environments [9]. Tall fescue (Lolium arundinaceum (Schreb.) S.J. Darbyshire), a cool-season perennial grass [10], is cultivated on an estimated 14-million hectares in the United States [11]. Tall fescue often forms an interdependent relationship with a shoot-specific fungal endophyte (Epichloë coenophiala) that produces ergot alkaloids that are toxic to livestock, causing fescue toxicosis or fescue foot $[12,13]$. To avoid fescue toxicosis, novel endophytes were identified and introduced into different tall fescue cultivars with non-toxic alkaloids such as lolines and peramines [14]. Although detrimental to livestock, tall fescue infected with Epichloë coenophiala has been shown to be persistent, exhibit better plant fitness, and offer improved ecosystem services over other grass species in pastures $[15,16]$. Endophyte infected tall fescue is a unique model to investigate the potential relationships between above and below-ground microbial communities. 
This potential relationship between the tall fescue, the endophyte, and the soil microbial communities might provide important insights to explore and clarify the plant's resilience against environmental stress and climate change, different soil biogeochemical processes that influence soil health, and vital ecosystem services. It is well documented that soil microbial communities impart significant benefits in soil nutrient cycling, soil fertility status, and soil carbon sequestration that influences plant fitness and survival in varying terrestrial ecosystems [17-19].

The soil microbiome composition is at the forefront of evolutionary ecology where the primary focus is on the identification of the beneficial microbial communities and comprehending the extent of influence on plant performance and soil health [20-22]. Soil nutrient status plays a central role in impacting soil bacterial and fungal communities. This is particularly true for phosphorus $(\mathrm{P})$, the least mobile macronutrient, found in the soil of the southeastern USA [23]. Due to its fixation with insoluble mineral-complex with iron $(\mathrm{Fe})$ and aluminum $(\mathrm{Al})$ oxides in acidic soil and with calcium (Ca) in alkaline soil, $\mathrm{P}$ is often limitedly released into the soil solution for root uptake [24,25]. Soil microbial communities, especially the phosphorus solubilizing microbial communities can secrete hydrolyzing enzymes, organic acids, protons, and phosphatases that can solubilize the organo-mineral complexes and release $\mathrm{P}$ and the associated mineral, eventually leading to the acquisition of unavailable P in soil by plants [26-30]. In return, the plant excreted rhizo-deposits and root architecture contribute significantly in the rhizosphere microbial communities [31]. Endophyte infection in tall fescue may offer a competitive advantage to non-infected fescue by influencing the soil microbial processes and soil microbial communities [32-34]. Additionally, the quantity and type of root exudates and rhizo-deposits change with different stages of plant development [35-37], thus, creating a resource partitioning in the soil that subsequently leads to niche partitioning [38-40]. In turn, given the rhizosphere origin of endophytic microbial populations, soil bacterial and fungal community composition may regulate the plant endophytic diversity and community composition [41]. In earlier studies based on the endophyte infection in tall fescue, shifts in soil microbial (bacterial and fungal) community structure and soil food webs have been reported [42,43]. These plant-fungal associations, especially in grass species, define a significant two-faceted interaction: (i) the collaboration gradient (above-ground) [44]; and (ii) root exudates mediated influence (below-ground) [45]. The first interaction describes how the plant-fungal symbiosis impacts nutrient foraging; promotes plant growth [46]; provides resilience against biotic stress, such as plant pathogens [47]; and abiotic stress, such as drought and salt tolerance [48]. The second interaction highlights the fungal communities associated with the rhizosphere communities, facilitates soil nutrient cycling and nutrient acquisition [49], organic matter decomposition [50,51], synthesis of phytohormones for root utilization [52], resistance against nematodes [53], and protection against pathogens [54]. Thus, determining the endophyte-facilitated soil microbial processes and the subsequent soil microbial response contributing to increased plant production and stress tolerance may carry significant economic and ecological importance for sustainable agricultural practices [55]. Our objective was to explore the diversity of the soil bacterial and fungal communities associated with tall fescue rhizosphere and investigate whether the bacterial and fungal populations differ based on the presence of endophyte in tall fescue.

\section{Materials and Methods}

\subsection{Site Description}

The study site was in the southeastern region of the USA at the J. Phil Campbell (JPC) Research and Education Center ( $33^{\circ} 52^{\prime} \mathrm{N}, 83^{\circ} 27^{\prime} \mathrm{W}$ ) and Iron Horse Farm (IHF) $\left(33^{\circ} 72^{\prime} \mathrm{N}, 83^{\circ} 30^{\prime} \mathrm{W}\right)$ in Watkinsville, Georgia. The soil at JPC is a fine kaolinitic, thermic Typic Kanhapludults in the Cecil sandy loam series with a $2 \%$ to $6 \%$ slope. The soil at IHF is Pacolet sandy clay loam, with a $6 \%$ to $10 \%$ slope [56]. The region has $123 \mathrm{~cm}$ average annual rainfall and an average minimum and maximum temperature of $10.4^{\circ} \mathrm{C}$ and $22.5^{\circ} \mathrm{C}$, respectively. Soil sampling for this study was completed in October 2019, following a 
summer that according to the National Oceanic and Atmospheric Administration had the hottest July on record, since the late 1800s. The research plots were established in the fall of 2014 with 750 different tall fescue accessions. Each tall fescue accession was planted in $1.5 \mathrm{~m}$ single row: $0.75 \mathrm{~m}$ space between plots within the range and $1.5 \mathrm{~m}$ between ranges. Since its establishment, the plots were fertilized with inorganic fertilizers (N-P-K) in October 2014 and regular clippings of the grass were performed every spring.

Table 1 shows the average atmospheric temperature, soil temperature, and average rainfall between 2014 to 2019 .

Table 1. Average maximum, minimum, and daily atmospheric temperature $\left({ }^{\circ} \mathrm{C}\right)$, average soil temperature $(0-15 \mathrm{~cm})\left({ }^{\circ} \mathrm{C}\right)$, and average rainfall (mm) during summer months (June, July, and August) from 2015 to 2019.

\begin{tabular}{cccccc}
\hline Season & $\begin{array}{c}\text { Maximum } \\
\text { Atmospheric } \\
\text { Temperature }\left({ }^{\circ} \mathbf{C}\right)\end{array}$ & $\begin{array}{c}\text { Minimum } \\
\text { Atmospheric } \\
\text { Temperature }\left({ }^{\circ} \mathbf{C}\right)\end{array}$ & $\begin{array}{c}\text { Daily Atmospheric } \\
\text { Temperature }\left({ }^{\circ} \mathbf{C}\right)\end{array}$ & $\begin{array}{c}\text { Daily Soil } \\
\text { Temperature }\left({ }^{\circ} \mathbf{C}\right) \\
\text { at 15 cm Depth }\end{array}$ & $\begin{array}{c}\text { Average Rainfall } \\
(\mathbf{m m})\end{array}$ \\
\hline Summer 2015 & 32 & 21 & 26 & 28 & 391 \\
Summer 2016 & 33 & 21 & 27 & 30 & 28 \\
Summer 2017 & 30 & 20 & 25 & 28 & 317 \\
Summer 2018 & 31 & 20 & 25 & 29 & 392 \\
Summer 2019 & 31 & 20 & 25 & 29 & \\
\hline
\end{tabular}

\subsection{Soil Sampling and Tall Fescue Plants}

We sampled soil from 48 different tall fescue accessions' rhizospheres with a hand soil probe $(2.5 \mathrm{~cm}$ diameter) to a depth of $0-15 \mathrm{~cm}$. All soil samples were kept refrigerated at $4{ }^{\circ} \mathrm{C}$. The soils were then air-dried, ground, and passed through a $2 \mathrm{~mm}$ sieve for soil nutrient analysis. Out of 48 tall fescue ranges, 43 ranges were planted at JPC and five were planted at the IHF site. We selected nine tall fescue cultivars with no endophytes $(E-)$ and 35 cultivars with endophyte infection (E+), among which 21 were infected with novel-endophytes and 14 with wild-type, toxic endophytes. At the time of soil sampling, for the purpose of microbial analysis, soil samples were immediately separated and kept at $-20{ }^{\circ} \mathrm{C}$ until the soil genomic DNA was extracted (see below Section 2.3).

\subsection{DNA Extraction, PCR Amplification, and $16 S$ rRNA Gene and ITS Gene Sequencing}

DNA Extraction, PCR Amplification, and 16S rRNA Gene and ITS Gene Sequencing from homogenized and frozen soil $(0.25 \mathrm{~g})$, soil DNA was extracted using QIAGEN DNeasy PowerSoil Kit (DNeasy PowerSoil Kit Handbook, May 2017, Qiagen, Valencia, CA, USA). Soil DNA quality and concentration were assessed by a NanoDrop 2000 spectrophotometer (Thermo Scientific, Waltham, MA, USA). Extracts were stored at $-20{ }^{\circ} \mathrm{C}$ until further analysis. A bacterial sequencing library targeting the bacterial 16S rRNA genes was prepared using primer sets from PacBio 16S protocol (V1-V9 regions) [57]; 27F27F (AGRGTTYGATYMTGGCTCAG)/14292R (RGYTACCTTGTTACGACTT). For the fungal sequencing library, we targeted the ITS region and used ITS1-F Forward (CTTGGTCATTTAGAGGAAGTAA)/ITS2-R Reverse (GCTGCGTTCTTCATCGATGC) to amplify the ITS region. The sequencing workflow was as follows: (i) Multiplexing with PacBio Barcoded Universal Primers; (ii) AMPure PB bead purification; (iii) Pooling Barcoded Amplicons; (iv) SMRTbell Library Construction; (v) Purification of SMRTbell Templates; (vi) Anneal and Bind SMRTbell Templates; and (vii) Sequencing on PacBio Sequel II System. The first-round amplification PCR conditions were $95^{\circ} \mathrm{C}$ for $180 \mathrm{~s}$, followed by 20 cycles of $95{ }^{\circ} \mathrm{C}$ for $30 \mathrm{~s}, 57{ }^{\circ} \mathrm{C}$ for $30 \mathrm{~s}$, and $72{ }^{\circ} \mathrm{C}$ for $60 \mathrm{~s}$ with universal primer-tailed 16S primers and ITS1 primers. The second-round amplification PCR conditions were $95^{\circ} \mathrm{C}$ for $30 \mathrm{~s}, 57^{\circ} \mathrm{C}$ for $30 \mathrm{~s}$, and $72{ }^{\circ} \mathrm{C}$ for $60 \mathrm{~s}$ for 20 cycles with PacBio Barcoded Universal Primers. SMRTbell libraries were prepared by using PacBio Barcoded Universal Primers for Multiplex SMRT Sequencing. Then, PacBio's single-molecule circular consensus sequencing (CCS) reads were generated for full-length 16S rRNA genes and ITS gene (accuracy of 99\%). The CCS reads were de-multiplexed using the software "lima" in 
SMRT Analysis software version 2.3.0. To generate bam files followed by a conversion to Fastq files via bam2fastq.

\subsection{Data Analysis}

The CCS reads were processed with DADA2 software packages (16S rRNA gene and ITS specific workflow) (version 1.8) [58], and analyzed with phyloseq for alpha and beta diversity (version 1.25.2) [59]. For 16s rRNA gene CCS data, the DADA2 workflow follows primer trimming, quality filtering, and de-replication. Amplicon sequence variants (ASVs) were inferred after learning the error rates. Afterward, the "removeBimeraDenovo" command was used to remove chimeras. Finally, we used the SILVA nr v132 train set to assign taxonomy. For the fungal data analysis, we followed the ITS-specific variation of the DADA2 package. In the fungal DADA2 workflow, after orienting the primers, we used a specialized primer/adapter removal tool "cutadapt" [60]. After primer removal, the next steps consist of quality filtering, de-replication, inferring ASVs after error learning, and finally removing chimeras. We used UNITE ITS database for taxonomic assignments [61]. The ASV tables from DADA2 pipelines were imported into phyloseq to make phyloseq objects and to calculate alpha and beta diversity. Sigma Plot 11 was used to generate figures depicting percentage of bacterial and fungal populations in soil.

\subsection{Statistical Analysis}

Analysis of variance with JMP PRO 15 software $\left(\mathrm{JMP}^{\circledR}\right.$, Version 15 . SAS Institute Inc., Cary, NC, USA, 1989-2019) was used to determine differences in soil pH, inorganic nitrogen, nitrate content, calcium, potassium, magnesium, phosphorus, and zinc, between endophyte-free fescue soil, non-toxic endophyte-infected fescue soil, and toxic endophyteinfected fescue soil samples $(p<0.05)$. Comparisons between multiple means of different soil nutrient content were completed with Tukey's HSD $(p<0.05)$.

\section{Results}

\subsection{Soil Chemical Properties}

There were no significant differences in soil $\mathrm{pH}$ and soil nutrient content between $\mathrm{E}-$ and E+ tall fescue soil, except for plant-available phosphorus in soil (Table 2). The $\mathrm{E}+$ tall fescue soil had higher plant-available P compared to the E- tall fescue soil. Between endophyte-free, non-toxic, and toxic endophyte-infected tall fescue soil, non-toxic endophyte-infected soil had significantly greater plant-available P compared to the rest (Table 2). Although, $\mathrm{Zn}$ content in soil was not statistically significant between the $\mathrm{E}-$ and E+ tall fescue soil, three endophyte-infected tall fescue soil samples, accession 1062, 1064, and Bar Optima had higher soil Zn content.

Table 2. Mean soil nitrogen $(\mathrm{N})$, calcium $(\mathrm{Ca})$, potassium $(\mathrm{K})$, magnesium $(\mathrm{Mg})$, manganese $(\mathrm{Mn})$, phosphorus $(\mathrm{P})$, and zinc (Zn) $(\mathrm{mg} / \mathrm{kg})$ content.

\begin{tabular}{|c|c|c|c|c|c|c|c|c|c|}
\hline & $\mathrm{pH}$ & $\mathrm{NH}_{4}{ }^{+}-\mathrm{N}$ & $\mathrm{NO}_{3}-\mathbf{N}$ & $\mathrm{Ca}$ & $\mathbf{K}$ & Mg & Mn & $\mathbf{P}$ & Zn \\
\hline Endophyte-Free Soil & $6.53^{\mathrm{a}}$ & $3^{a}$ & $244^{\mathrm{a}}$ & $801^{\mathrm{a}}$ & $40^{\mathrm{a}}$ & $105^{\mathrm{a}}$ & $17^{\mathrm{a}}$ & $26^{b}$ & $1.0^{\mathrm{a}}$ \\
\hline Endophyte-Infected Soil (Toxic) & $6.59^{a}$ & $2^{a}$ & $270^{\mathrm{a}}$ & $681^{\mathrm{a}}$ & $43^{\mathrm{a}}$ & $93^{\mathrm{a}}$ & $17^{\mathrm{a}}$ & $38^{\mathrm{a}}$ & $1.17^{\mathrm{a}}$ \\
\hline $\begin{array}{l}\text { Endophyte-Infected Soil } \\
\text { (Non-toxic) }\end{array}$ & $6.59^{a}$ & $3^{a}$ & $245^{\mathrm{a}}$ & $731^{\mathrm{a}}$ & $45^{\mathrm{a}}$ & $99^{a}$ & $16^{\mathrm{a}}$ & $33^{\mathrm{ab}}$ & $1.07^{\mathrm{a}}$ \\
\hline
\end{tabular}

Different lower-case letters indicate a significant difference between endophyte-free soil, toxic endophyte-infected soil, and non-toxic endophyte-infected soil $(p<0.05)$.

\subsection{Soil Bacterial Abundance, Diversity, and Community Composition}

We identified 1212 and 3411 bacterial amplicon sequence variants (ASVs) in the Eand $\mathrm{E}+$ tall fescue soil collected from the tall fescue plots, respectively. We identified 18 phyla, 29 classes, 72 orders, 111 families, and 151 bacterial genera in E+ tall fescue soil. In E- tall fescue soil, we identified 14 phyla, 29 classes, 45 orders, 88 families, and 
97 bacterial genera. The Shannon diversity index (SDI) highlights the species' richness and evenness among the entire community; the higher number indicates higher diversity. The mean bacterial Shannon diversity index was lower overall and not statistically significant between the $\mathrm{E}-\left(\right.$ mean $\left.\mathrm{H}^{\prime}=4.5\right)$ and $\mathrm{E}+\left(\right.$ mean $\left.\mathrm{H}^{\prime}=4.0\right)$ soil. Additionally, bacterial beta-diversity presented with principal coordinate analysis (PCoA) based on Bray-Curtis dissimilarities showed no significant differences between soil microbial communities based on the presence of endophyte in tall fescue. The prominent bacterial phylum in both E- and E+ tall fescue soil was Planctomycetes (Figure 1a,b). In E+ tall fescue soil, the abundance of phyla from greatest to lowest was as follows: Planctomycetes $(28 \%)>$ Proteobacteria $(20 \%)>$ Acidobacteria $(12 \%)>$ Bacteroidetes $(9 \%)>$ Firmicutes $(6 \%)>$ Verrucomicrobia, Chloroflexi and Actinobacteria (5\%) > Gemmatimonadetes and Nitrospira (2\%) (Figure 1a). For E- tall fescue soil, from greatest to lowest abundance of the prominent bacterial phyla was as follows: Planctomycetes $(30 \%)>$ Proteobacteria $(18 \%)>$ Acidobacteria $(7 \%)>$ Bacteroidetes $(10 \%)>$ Firmicutes, Verrucomicrobia, Chloroflexi $(6 \%)>$ Actinobacteria $(4 \%)$ $>$ Gemmatimonadetes and Nitrospira (2\%) (Figure 1b).

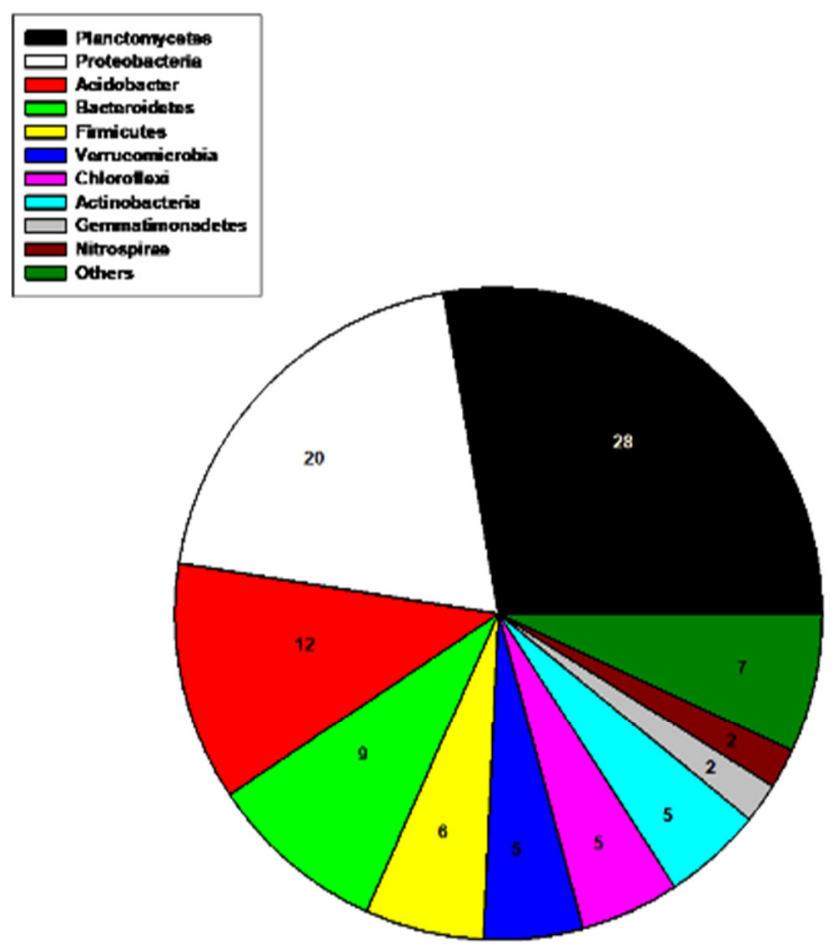

a. Endophyte Infected

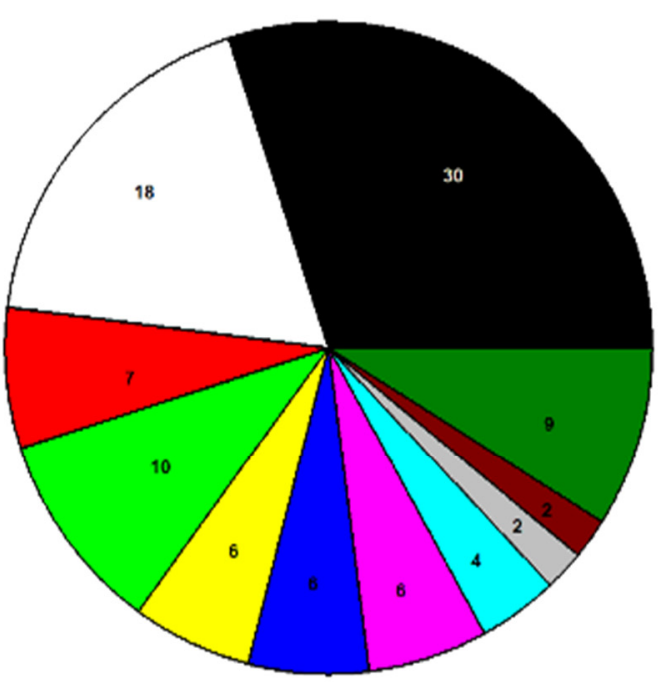

b. Endophyte free

Figure 1. (a,b) Prominent bacterial phyla in soil based on endophyte presence in tall fescue.

Prominent bacterial families between E- and E+ soil was Planctomycetaceae, Balstocatellaceae_(subgroup_4), Chitinophagaceae, and Bacillaceae (Figure 2). Moreover, we found several characteristics including: nitrogen-utilizing, phosphorus solubilizing, bio-controller, chitin degrading, nitrate reducers, drought and salt tolerant, and other nutrient solubilizing bacterial families, for instance, Planctomycetaceae, Xanthobacteraceae, Flavobacteriaceae, Bradyrhizobiaceae, Acidobacteriaceae_(Subgroup_1),DA101_soil_group, Anaerolineaceae, Nitrosomonadaceae, Tepidisphaeraceae, Gemmatimonadaceae, Cytophagaceae, Burkholderiaceae, and Comamonadaceae (Figure 2 and Supplemental Material S1). Endophyte-free tall fescue soil had higher Planctomycetaceae (31\% of Planctomycetes) and Chitinophagaceae (10\% of Bacteroidetes) compared to the E+ soil, where the Balstocatellaceae_(subgroup_4) (7\% of Acidobacteria) and Bacillaceae (5\% of Firmicutes) were higher (Figure 2). 


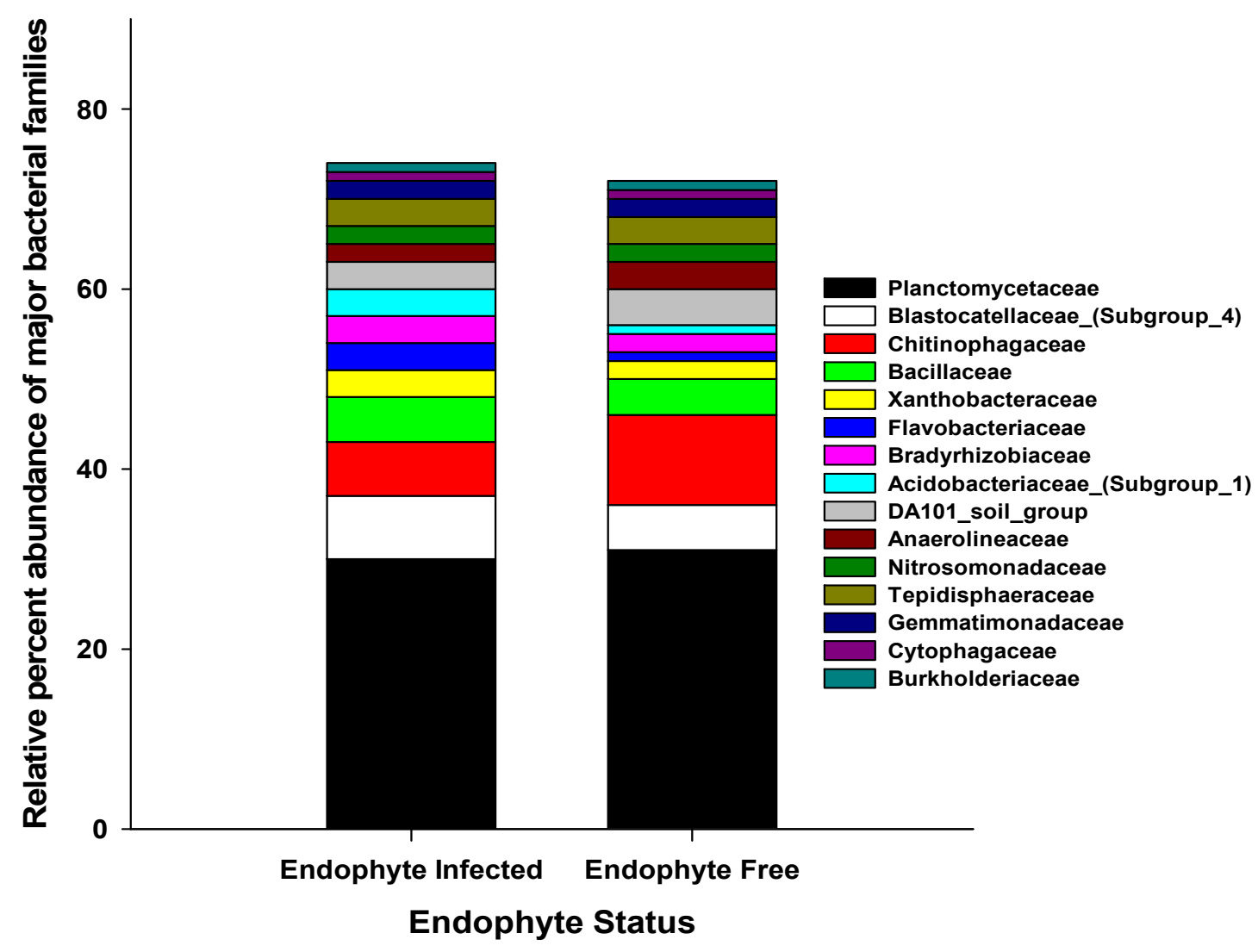

Figure 2. Relative percent abundance of bacterial families in tall fescue soil.

\subsection{Soil Fungal Abundance, Diversity, and Community Composition}

We identified 71 and 652 fungal ASVs in the E- and E+ tall fescue soil collected from the tall fescue plots, respectively. In E+ tall fescue soil, we identified 6 phyla, 24 classes, 43 orders, 76 families, and 112 bacterial genera. We identified 3 phyla, 6 classes, 10 orders, 18 families, and only 19 bacterial genera in $\mathrm{E}-$ tall fescue soil. In both $\mathrm{E}-$ and $\mathrm{E}+$ tall fescue soil, the dominant fungal phyla consisted of Basidiomycota and Ascomycota, respectively (Figure 3a,b). The mean fungal Shannon diversity index was lower overall and was not statistically significant between the $\mathrm{E}-\left(\right.$ mean $\left.\mathrm{H}^{\prime}=1.21\right)$ and $\mathrm{E}+\left(\right.$ mean $\left.\mathrm{H}^{\prime}=1.27\right)$ soil. Fungal beta diversity presented with principal coordinate analysis (PCOA) based on BrayCurtis dissimilarities also showed no significant differences. Interestingly, however, we did observe a fungal community shift between $\mathrm{E}-$ and $\mathrm{E}+$ tall fescue soil. While Basidiomycota $(70 \%)$ dominated E- soil, E+ soil had Ascomycota as the prominent phylum (Figure 3a,b). Based on the toxicity status of the endophyte presence in the tall fescue, E+ soil showed a similar percent abundance at phyla level where both toxic and non-toxic infected tall fescue soil had Ascomycota as the prominent phylum (Figure 4). Arbuscular mycorrhizal fungi (AMF) belonging to Glomeromycota phylum (1\% of the total fungal abundance) were identified in only E+ fescue soil (Figure 3a). In the case of fungal genera, while E+ soil had no such genus that exceeded more than $5 \%$ of the total abundance, the most prominent genus in E- soil belonged to Cortinarius (59\% of Basidiomycota) (Figure 5). Interestingly, we measured greater diversity at the genus level in E+ soil (111 genera) compared to E- soil (19 genera). These different fungal genera have been shown to contribute to: plant growth promotion, plant-pathogen suppression, lignin degradation, nitrogen utilization, phosphorus solubilization, biodegradation, phytohormone production, and provides resistance against abiotic stresses such as drought, salt intrusion, and cold tolerance, etc. (Figure 5 and Supplemental Material S2). 


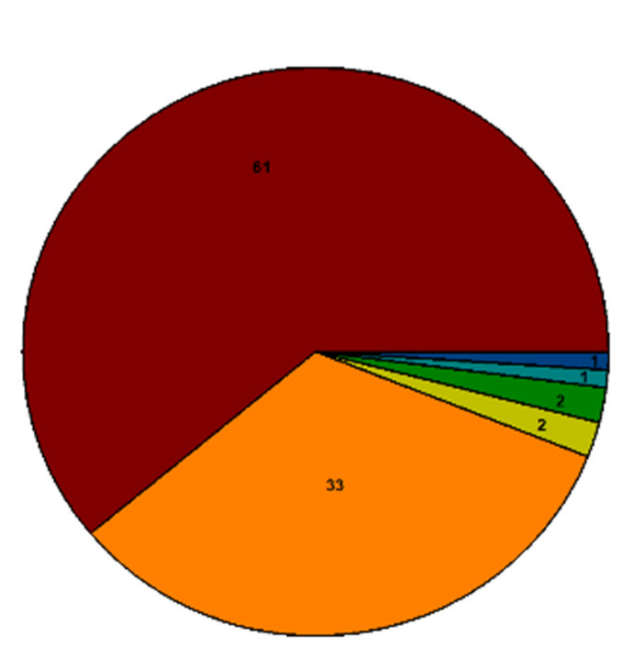

a. Endophyte Infected

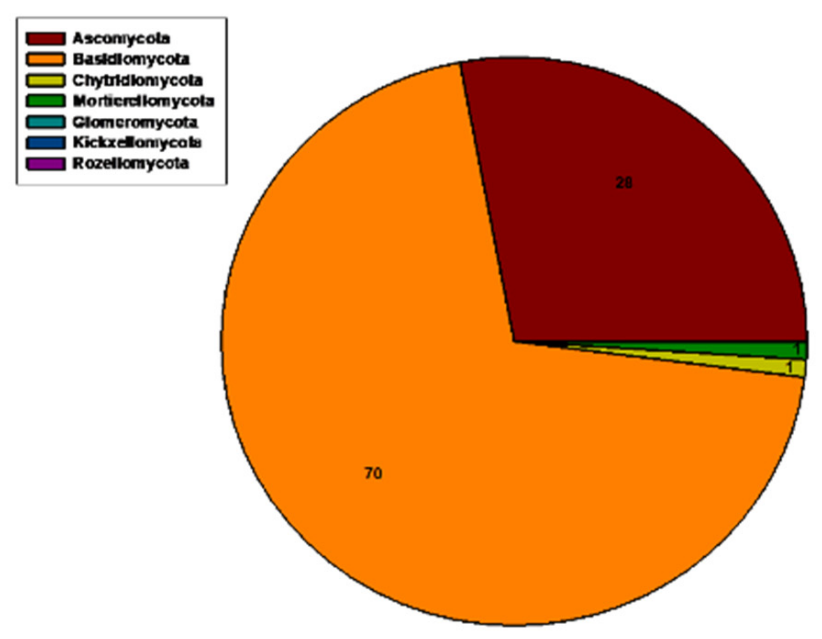

b. Endophyte free

Figure 3. (a,b) Distribution of major fungal phyla in soil based on endophyte presence in tall fescue.

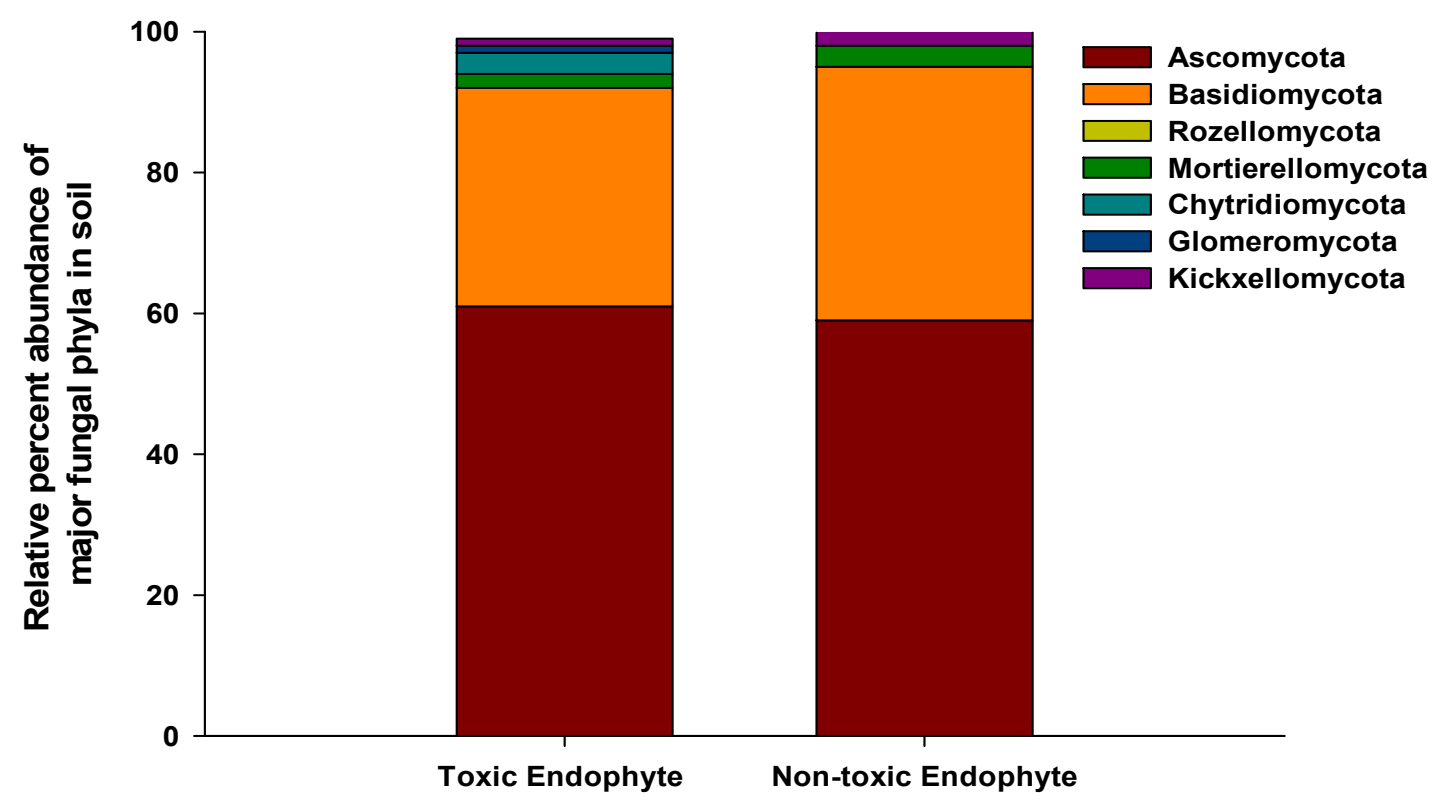

Figure 4. Prominent fungal phyla in soil based on endophyte toxicity in tall fescue. 


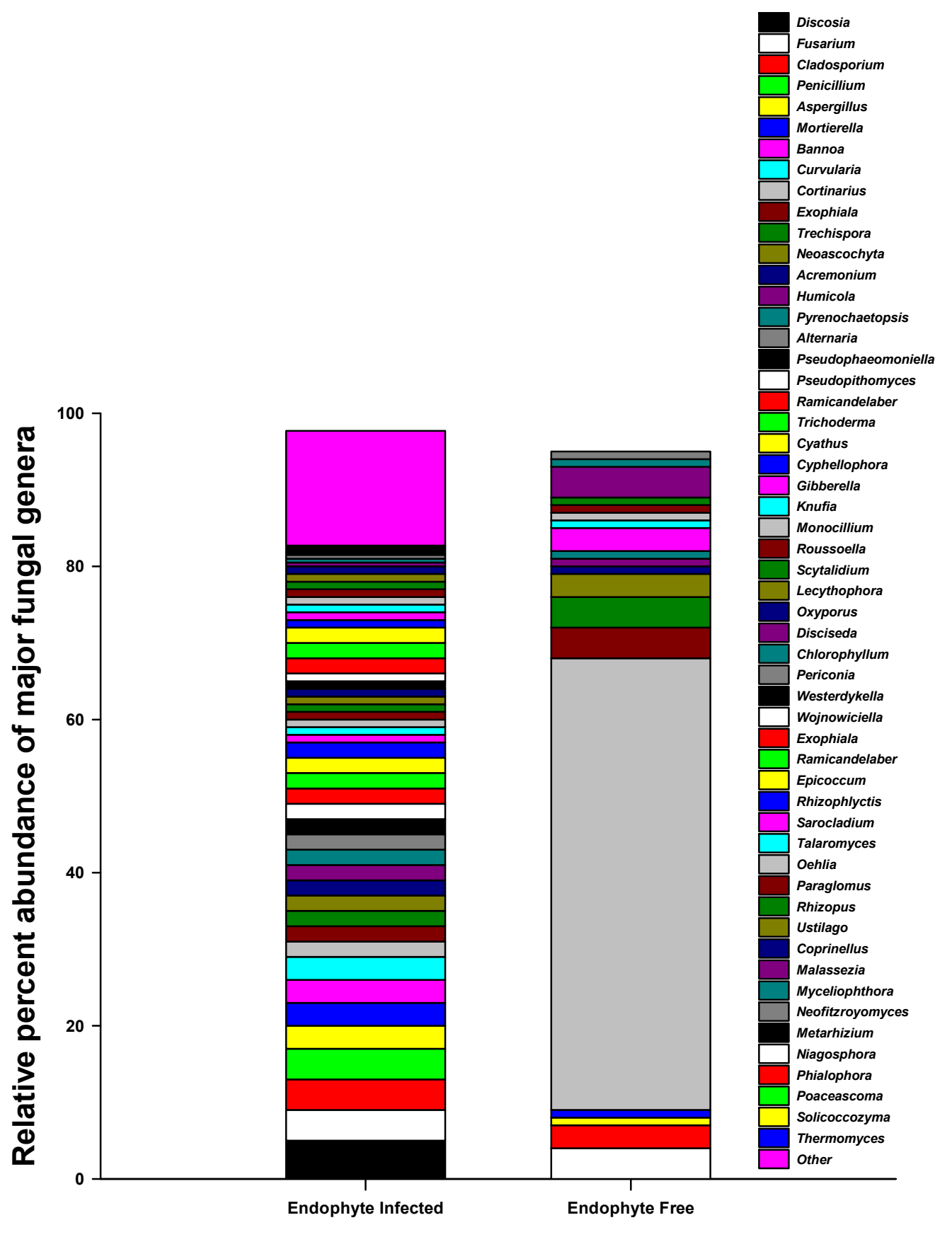

\section{Endophyte Status}

Figure 5. Relative percent abundance of fungal genres in tall fescue soil.

\section{Discussion}

Despite the intricate nature of soil microbial populations, we found common patterns in bacterial community responses in the soil to the endophyte presence in tall fescue and our results from soil bacterial analysis indicate that the endophyte presence in tall fescue might have had a subtle effect on the bacterial community composition. Contrasting results, however, have been reported on the impact of the endophyte presence in grass species on soil microbial community composition and microbial functions [62]. For instance, soil microbial communities may alter microbial functions due to above-ground endophyte infection of grass species, such as microbial carbon and nitrogen mineralization [32,63-65]. Furthermore, endophyte infection of above-ground plant material stimulated below-ground 
microbial functions primarily due to endophyte-induced rhizodeposition [66]. In our study, the lack of bacterial diversity in community composition perhaps can be speculated to the soil micro-niche effect [67]. Due to the size of bacteria, they are expected to be in direct contact with their immediate surroundings, but often these micro-niches have a different composition from the soil matrix [68]; thus, plant roots may never come into direct contact with the bacterial communities living in these niches and perhaps never influence the community composition of the bacteria living in soils [69].

In our study, Planctomycetes were the dominant oligotrophic phylum (r-strategists) found in both E+ and E- tall fescue rhizosphere soils and they are well suited for nutrientpoor soil indicated by lower soil carbon and phosphorus [70-73]. They are thought to be crucial in soil organic carbon and complex carbon turnover, nitrogen cycling, and subsequently for soil nutrient availability [74-76]. The second dominant bacterial phylum for both E+ and E- tall fescue soil was a versatile group of copiotroph, known as Proteobacteria, that responds to readily available carbon in soil [75,77]. Additionally, these Proteobacteria follow a fast growth pattern in the soil, which consequently may act as a plant growth promoter by releasing soil macro and micro-nutrients from organo-mineral complexes [78,79], especially under copiotroph environments [80]. It is well documented that by producing metabolites of fungal-origin, $\mathrm{E}+$ tall fescue has a competitive advantage over E- grasses, particularly against climatic and edaphic stress, protection against herbivores, enhanced nutrient acquisition, for instance soluble $P$ in nutrient-poor soils [81-83]. In our study, another oligotroph microbial taxa, Acidobacter, was found in greater relative percent abundance in E+ tall fescue rhizosphere soil, like Planctomycetes, offers efficient carbon and nitrogen cycling from soil organic matter that can consequently be used as a readily available nutrient source for the E+ plants [75,84]. The Proteobacteria to Acidobacteria $(\mathrm{P} / \mathrm{A})$ ratio may serve as a general indicator of soil nutrient status; a low $\mathrm{P} / \mathrm{A}$ ratio indicates oligotrophic soil environment and a high $\mathrm{P} / \mathrm{A}$ ratio suggests nutrient richness [85]. In our study, the percent abundance ratio of Proteobacteria/Acidobacteria $(\mathrm{P} / \mathrm{A})$ was lower in E+ tall fescue rhizosphere soil (1.66) compared to E- tall fescue rhizosphere soil (2.57). In general, E- tall fescue performs poorer in overall plant fitness and persistence [86], despite the higher soil nutrient status (indicated by high P/A), compared to E+ infected fescue, possibly due to the lower percent abundance of the Acidobacter phylum. Additionally, known copiotrophs, such as Bacteroidetes and Verrucomicrobia, were also present in relatively lower abundance, possibly, due to the overall lower nutrient concentration of the study site $[87,88]$.

In the case of fungal community composition in soil, endophyte presence in tall fescue showed a clear shift in fungal phyla in the rhizosphere. In agroecosystems, strong evidence of multilateral interactions between plant population, soil fungi, and soil solution composition has been discovered [69,89-91]. The complex fungal community structure and greater diversity enable enhanced organic matter decomposition, thereby promoting higher nutrient absorption by plants and accelerated soil nutrient cycling [92-94]. The plants act as the energy source for the soil fungal population by releasing photosynthetic carbon and secondary metabolites in soil [95-99], thus creating a feedback loop. Thus, soil fungal diversity has a remarkable influence on the fitness of the plant population, soil nutrient composition, and is vastly influenced by the presence of endophytes in plants [100-102]. The three prominent fungal phyla in soil are the Ascomycota, Zygomycota, and Basidiomycota [89], and our study site was dominated by either Ascomycota or Basidiomycota depending on the presence of endophytes in tall fescue (not the type of endophytes; toxic or non-toxic). The lower SDI measured for the fungal population in the soil, both E+ and $\mathrm{E}-$, may have been due to the overall higher soil $\mathrm{pH}$ of the study site; fungi generally grow better in acidic conditions [103], whereas, our study site had an average soil $\mathrm{pH}$ of 6.5. The greater relative abundance of Ascomycota and Basidiomycota in E+ and E- tall fescue rhizosphere soil, respectively, suggests that the presence of endophyte in tall fescue affects the rhizosphere fungal community structure, possibly through a combination of: (i) alkaloids such as loline or peramine excretion in the host grass [104,105]; (ii) production 
of VOCs and other biochemical induced by the tall fescue [106,107]; and finally, (iii) higher rhizodeposition [108], all of which finally contribute to increased resource availability for soil fungi. This, therefore, is an indication of a three-way relationship between the plant (tall fescue), fescue-dwelling fungal endophytes, and the soil fungal communities [109]. Furthermore, significantly greater plant-available $\mathrm{P}$ in $\mathrm{E}+$ soil compared to E- soil (Table 2), particularly in non-toxic E+ soil, suggests the unique contribution of a less studied novel endophyte-host associations to plant nutrition under limited soil plant-available P [110]. This plant-available $P$ in conjunction with the combined presence of Ascomycota, Basidiomycota, and Glomeromycota in E+ tall fescue soil in the rhizosphere is likely to contribute to plant and soil microbial communities' growth [111]. A highly diverse soil microbial community can withstand the changing environment, show greater resilience, and may bring stability in ecosystem functioning [112-115]. The observed higher diversity of fungal genera in E+ tall fescue soil is particularly important under a stressed environment because of their impact on plant growth and higher stress amelioration $[20,116]$. Often, carbon acquisition can be strictly limited under abiotic stress, such as drought, and the plantassociated microbial communities lacks the necessary resources to sustain [117]. However, soil fungal communities may indirectly stimulate photosynthesis in plants by providing necessary nutrients [118]. Thus, the presence of a complex fungal assemblage at genus level in E+ tall fescue soil suggests (Figure 5) that root excreted rhizo-deposits from E+ tall fescue into the soil may have enhanced the mobilization or recruitment of beneficial rhizosphere fungal communities, and in turn, these different soil fungal communities possibly could provide greater fitness and resilience to the plant [119-121]. In addition, a greater number of fungal genera in the soil is also important in offering higher functional redundancy for both "basic" and "rare" soil functions [121], particularly under disturbed environments, hence, the greater distribution of different functional groups is a clear indicator of greater functional redundancy [78] in E+ soil compared to E- soil.

\section{Conclusions}

Our study suggests that a three-way mutualistic relationship exists between tall fescue, fungal endophyte, and the soil rhizosphere communities, particularly the soil fungal community. This study reveals that while there was a subtle change in the soil bacterial population based on endophyte presence in above-ground tall fescue, prominent changes were observed in the fungal community at the genus level compared to the endophyte-free soil. These results point to the possibility that the different soil nutrient acquisition and environmental stress tolerance imparted by endophytes on tall fescue is probably the result of mobilization or recruiting of beneficial rhizosphere microorganisms; however, further field trials of different endophytes in common plant genetic backgrounds are needed to confirm this.

Supplementary Materials: The following are available online at https:/ /www.mdpi.com/article/ 10.3390/microorganisms9091843/s1, Supplemental Material S1: Prominent bacterial families (\%) present in endophyte infected and endophyte free tall fescue soil, Supplemental Material S2: Prominent fungal genres (\%) present in endophyte infected and endophyte free tall fescue soil.

Author Contributions: Conceptualization, K.M.; Formal analysis, K.M.; Funding acquisition, A.M. (Ali Missaoui); Investigation, K.M. and A.M. (Ali Missaoui); Methodology, K.M., K.L., and A.M. (Ali Missaoui); Project administration, A.M. (Ali Missaoui); Resources, A.M. (Ali Missaoui); Supervision, A.M. (Ali Missaoui); Validation, N.S.H. and A.M. (Ali Missaoui); Visualization, K.M.; Writingoriginal draft, K.M. and K.L.; Writing—review and editing, N.S.H., A.M. (Anaas Mergoum), and A.M. (Ali Missaoui). All authors have read and agreed to the published version of the manuscript.

Funding: This research was funded by The Center for Bioenergy Innovation, US Department of Energy Research Center supported by the Office of Biological and Environmental Research in the DOE Office of Science.

Institutional Review Board Statement: Not applicable. 
Informed Consent Statement: Not applicable.

Data Availability Statement: The datasets during and/or analyzed during the current study is available from the corresponding author on reasonable request.

Acknowledgments: The authors are grateful to Savin Khadka, Agricultural Economics, University of Georgia for his initial support with R-Studio software. The authors also acknowledge Jonathan Markham for his help with soil sampling.

Conflicts of Interest: The authors declare no conflict of interest. The funders had no role in the design of the study; in the collection, analyses, or interpretation of data; in the writing of the manuscript, or in the decision to publish the results.

\section{References}

1. Shantz, H. The place of grasslands in the Earth's cover. Ecology 1954, 35, 143-145. [CrossRef]

2. Dixon, A.; Faber-Langendoen, D.; Josse, C.; Morrison, J.; Loucks, C. Distribution mapping of world grassland types. J. Biogeogr. 2014, 41, 2003-2019. [CrossRef]

3. Wedin, W.F. Grassland: Quietness and Strength for a New American Agriculture; ASA-CSSA-SSSA: Madison, WI, USA, 2009; Volume 142.

4. Deng, L.; Shangguan, Z.-P.; Sweeney, S. “Grain for Green” driven land use change and carbon sequestration on the Loess Plateau, China. Sci. Rep. 2014, 4, 7039. [CrossRef]

5. Endale, D.; Schomberg, H.; Franzluebbers, A.; Seman, D.; Franklin, D.; Stuedemann, J. Runoff nutrient losses from tall fescue pastures varying in endophyte association, fertilization, and harvest management. J. Soil Water Conserv. 2021, 76, 25-38. [CrossRef]

6. Sala, O.E.; Yahdjian, L.; Havstad, K.; Aguiar, M.R. Rangeland ecosystem services: Nature's supply and humans' demand. In Rangeland Systems; Springer: Cham, Switzerland, 2017; pp. 467-489.

7. Zhao, Y.; Liu, Z.; Wu, J. Grassland ecosystem services: A systematic review of research advances and future directions. Landsc. Ecol. 2020, 35, 1-22. [CrossRef]

8. Leuchtmann, A. Systematics, distribution, and host specificity of grass endophytes. Nat. Toxins 1993, 1, 150-162. [CrossRef]

9. Field, K.J.; Pressel, S.; Duckett, J.G.; Rimington, W.R.; Bidartondo, M.I. Symbiotic options for the conquest of land. Trends Ecol. Evol. 2015, 30, 477-486. [CrossRef] [PubMed]

10. Bouton, J.; Gates, R.; Belesky, D.; Owsley, M. Yield and persistence of tall fescue in the southeastern coastal plain after removal of its endophyte. Agron. J. 1993, 85, 52-55. [CrossRef]

11. Young, C.A.; Charlton, N.D.; Takach, J.E.; Swoboda, G.A.; Trammell, M.A.; Huhman, D.V.; Hopkins, A.A. Characterization of Epichloë coenophiala within the US: Are all tall fescue endophytes created equal? Front. Chem. 2014, 2, 95. [CrossRef]

12. Hoveland, C.S. Importance and economic significance of the Acremonium endophytes to performance of animals and grass plant. Agric. Ecosyst. Environ. 1993, 44, 3-12. [CrossRef]

13. Stuedemann, J.A.; Hoveland, C.S. Fescue endophyte: History and impact on animal agriculture. J. Prod. Agric. 1988, 1, 39-44. [CrossRef]

14. Hunt, M.G.; Newman, J.A. Reduced herbivore resistance from a novel grass-endophyte association. J. Appl. Ecol. 2005, 42, 762-769. [CrossRef]

15. Parish, J.; McCann, M.; Watson, R.; Paiva, N.; Hoveland, C.; Parks, A.; Upchurch, B.; Hill, N.; Bouton, J. Use of nonergot alkaloid-producing endophytes for alleviating tall fescue toxicosis in stocker cattle. J. Anim. Sci. 2003, 81, 2856-2868. [CrossRef]

16. Hill, N.; Bouton, J.; Hiatt, E.; Kittle, B. Seed maturity, germination, and endophyte relationships in tall fescue. Crop Sci. 2005, 45, 859-863. [CrossRef]

17. Wang, H.; Wang, S.; Wang, R.; Wang, X.; Li, J. Conservation tillage increased soil bacterial diversity and improved soil nutrient status on the Loess Plateau in China. Arch. Agron. Soil Sci. 2020, 66, 1509-1519. [CrossRef]

18. Koyama, A.; Wallenstein, M.D.; Simpson, R.T.; Moore, J.C. Soil bacterial community composition altered by increased nutrient availability in Arctic tundra soils. Front. Microbiol. 2014, 5, 516. [CrossRef]

19. Lehman, R.M.; Acosta-Martinez, V.; Buyer, J.S.; Cambardella, C.A.; Collins, H.P.; Ducey, T.F.; Halvorson, J.J.; Jin, V.L.; Johnson, J.M.; Kremer, R.J. Soil biology for resilient, healthy soil. J. Soil Water Conserv. 2015, 70, 12A-18A. [CrossRef]

20. Porter, S.S.; Bantay, R.; Friel, C.A.; Garoutte, A.; Gdanetz, K.; Ibarreta, K.; Moore, B.M.; Shetty, P.; Siler, E.; Friesen, M.L. Beneficial microbes ameliorate abiotic and biotic sources of stress on plants. Funct. Ecol. 2020, 34, 2075-2086. [CrossRef]

21. Busby, P.E.; Soman, C.; Wagner, M.R.; Friesen, M.L.; Kremer, J.; Bennett, A.; Morsy, M.; Eisen, J.A.; Leach, J.E.; Dangl, J.L. Research priorities for harnessing plant microbiomes in sustainable agriculture. PLoS Biol. 2017, 15, e2001793. [CrossRef] [PubMed]

22. Mahmud, K.; Missaoui, A.; Lee, K.C.; Ghimire, B.; Presley, H.W.; Makaju, S. Rhizosphere Microbiome Manipulation for Sustainable Crop Production. Curr. Plant Biol. 2021, 27, 100210. [CrossRef]

23. Hinsinger, P. Bioavailability of soil inorganic P in the rhizosphere as affected by root-induced chemical changes: A review. Plant Soil 2001, 237, 173-195. [CrossRef] 
24. Akhtar, M.S.; Oki, Y.; Adachi, T. Mobilization and Acquisition of Sparingly Soluble P-Sources by Brassica Cultivars under P-Starved Environment II. Rhizospheric pH changes, Redesigned Root Architecture and Pi-Uptake Kinetics. J. Integr. Plant Biol. 2009, 51, 1024-1039. [CrossRef] [PubMed]

25. Bertrand, I.; Holloway, R.; Armstrong, R.; McLaughlin, M. Chemical characteristics of phosphorus in alkaline soils from southern Australia. Soil Res. 2003, 41, 61-76. [CrossRef]

26. Yang, X.J.; Finnegan, P.M. Regulation of phosphate starvation responses in higher plants. Ann. Bot. 2010, 105, 513-526. [CrossRef] [PubMed]

27. Gu, M.; Chen, A.; Sun, S.; Xu, G. Complex regulation of plant phosphate transporters and the gap between molecular mechanisms and practical application: What is missing? Mol. Plant 2016, 9, 396-416. [CrossRef] [PubMed]

28. Aslam, M.M.; Akhtar, K.; Karanja, J.K.; Haider, F.U. Understanding the Adaptive Mechanisms of Plant in Low Phosphorous Soil. In Plant Stress Physiology; IntechOpen: London, UK, 2020.

29. Batool, S.; Iqbal, A. Phosphate solubilizing rhizobacteria as alternative of chemical fertilizer for growth and yield of Triticum aestivum (Var. Galaxy 2013). Saudi J. Biol. Sci. 2019, 26, 1400-1410. [CrossRef]

30. Suleman, M.; Yasmin, S.; Rasul, M.; Yahya, M.; Atta, B.M.; Mirza, M.S. Phosphate solubilizing bacteria with glucose dehydrogenase gene for phosphorus uptake and beneficial effects on wheat. PLoS ONE 2018, 13, e0204408. [CrossRef] [PubMed]

31. Hernández, I.; Munné-Bosch, S. Linking phosphorus availability with photo-oxidative stress in plants. J. Exp. Bot. 2015, 66, 2889-2900. [CrossRef]

32. Buyer, J.S.; Zuberer, D.A.; Nichols, K.A.; Franzluebbers, A.J. Soil microbial community function, structure, and glomalin in response to tall fescue endophyte infection. Plant Soil 2011, 339, 401-412. [CrossRef]

33. Iqbal, J.; Siegrist, J.A.; Nelson, J.A.; McCulley, R.L. Fungal endophyte infection increases carbon sequestration potential of southeastern USA tall fescue stands. Soil Biol. Biochem. 2012, 44, 81-92. [CrossRef]

34. Matthews, J.W.; Clay, K. Influence of fungal endophyte infection on plant-soil feedback and community interactions. Ecology 2001, 82, 500-509.

35. Berg, G.; Smalla, K.J.F.m.e. Plant species and soil type cooperatively shape the structure and function of microbial communities in the rhizosphere. FEMS Microbiol. Ecol. 2009, 68, 1-13. [CrossRef] [PubMed]

36. Rovira, A.J.P. Root excretions in relation to the rhizosphere effect. Plant Soil 1959, 11, 53-64. [CrossRef]

37. Warembourg, F.; Paul, E.J.P. The use of $\mathrm{C}_{14} \mathrm{O}_{2}$ canopy techniques for measuring carbon transfer through the plant-soil system. Plant Soil 1973, 38, 331-345. [CrossRef]

38. Jones, D.L.; Hodge, A.; Kuzyakov, Y.J.N.P. Plant and mycorrhizal regulation of rhizodeposition. New Phytol. 2004, 163, 459-480. [CrossRef] [PubMed]

39. Marschner, P.; Neumann, G.; Kania, A.; Weiskopf, L.; Lieberei, R.J.P. Spatial and temporal dynamics of the microbial community structure in the rhizosphere of cluster roots of white lupin (Lupinus albus L.). Plant Soil 2002, 246, 167-174. [CrossRef]

40. Shi, S.; Richardson, A.E.; O'Callaghan, M.; DeAngelis, K.M.; Jones, E.E.; Stewart, A.; Firestone, M.K.; Condron, L.M.J.F.m.e. Effects of selected root exudate components on soil bacterial communities. FEMS Microbiol. Ecol. 2011, 77, 600-610. [CrossRef]

41. Yang, Y.; Chen, S.; Wu, X.; Syed, S.I.; Syed, I.U.S.; Huang, B.; Guan, P.; Wang, D. Grazing Affects Bacterial and Fungal Diversities and Communities in the Rhizosphere and Endosphere Compartments of Leymus chinensis through Regulating Nutrient and Ion Distribution. Microorganisms 2021, 9, 476. [CrossRef]

42. Rudgers, J.A.; Clay, K. An invasive plant-fungal mutualism reduces arthropod diversity. Ecol. Lett. 2008, 11, 831-840. [CrossRef] [PubMed]

43. Bergmann, J.; Weigelt, A.; van Der Plas, F.; Laughlin, D.C.; Kuyper, T.W.; Guerrero-Ramirez, N.; Valverde-Barrantes, O.J.; Bruelheide, H.; Freschet, G.T.; Iversen, C.M. The fungal collaboration gradient dominates the root economics space in plants. Sci. Adv. 2020, 6, eaba3756. [CrossRef] [PubMed]

44. Hu, L.; Robert, C.; Cadot, S.; Zhang, X.; Ye, M.; Li, B.; Manzo, D.; Chervet, N.; Steinger, T.; Van Der Heijden, M. Root exudate metabolites drive plant-soil feedbacks on growth and defense by shaping the rhizosphere microbiota. Nat. Commun. 2018, 9, 2738. [CrossRef] [PubMed]

45. Zhang, J.; Wang, P.; Xue, K.; Hao, Y.; Wang, Y.; Cui, X. Trait complementarity between fine roots of Stipa purpurea and their associated arbuscular mycorrhizal fungi along a precipitation gradient in Tibetan alpine steppe. J. Mt. Sci. 2019, 16, 542-547. [CrossRef]

46. Waqas, M.; Khan, A.L.; Hamayun, M.; Shahzad, R.; Kim, Y.-H.; Choi, K.-S.; Lee, I.-J. Endophytic infection alleviates biotic stress in sunflower through regulation of defence hormones, antioxidants and functional amino acids. Eur. J. Plant Pathol. 2015, 141, 803-824. [CrossRef]

47. Rana, K.L.; Kour, D.; Sheikh, I.; Dhiman, A.; Yadav, N.; Yadav, A.N.; Rastegari, A.A.; Singh, K.; Saxena, A.K. Endophytic fungi: Biodiversity, ecological significance, and potential industrial applications. In Recent Advancement in White Biotechnology through Fungi; Springer: Berlin/Heidelberg, Germany, 2019; pp. 1-62.

48. Hacquard, S.; Kracher, B.; Hiruma, K.; Münch, P.C.; Garrido-Oter, R.; Thon, M.R.; Weimann, A.; Damm, U.; Dallery, J.-F.; Hainaut, M. Survival trade-offs in plant roots during colonization by closely related beneficial and pathogenic fungi. Nat. Commun. 2016, 7 , 11362. [CrossRef] [PubMed]

49. Frąc, M.; Hannula, S.E.; Bełka, M.; Jędryczka, M. Fungal biodiversity and their role in soil health. Front. Microbiol. 2018, 9, 707. [CrossRef] [PubMed] 
50. Daws, S.C.; Cline, L.A.; Rotenberry, J.; Sadowsky, M.J.; Staley, C.; Dalzell, B.; Kennedy, P.G. Do shared traits create the same fates? Examining the link between morphological type and the biogeography of fungal and bacterial communities. Fungal Ecol. 2020, 46, 100948. [CrossRef]

51. Etesami, H.; Alikhani, H.A.; Hosseini, H.M. Indole-3-acetic acid (IAA) production trait, a useful screening to select endophytic and rhizosphere competent bacteria for rice growth promoting agents. MethodsX 2015, 2, 72-78. [CrossRef]

52. Qiu, W.; Su, H.; Yan, L.; Ji, K.; Liu, Q.; Jian, H. Organic Fertilization Assembles Fungal Communities of Wheat Rhizosphere Soil and Suppresses the Population Growth of Heterodera avenae in the Field. Front. Plant Sci. 2020, 11, 1225. [CrossRef]

53. Kour, D.; Rana, K.L.; Yadav, N.; Yadav, A.N.; Singh, J.; Rastegari, A.A.; Saxena, A.K. Agriculturally and industrially important fungi: Current developments and potential biotechnological applications. In Recent Advancement in White Biotechnology through Fungi; Springer: Berlin/Heidelberg, Germany, 2019; pp. 1-64.

54. Kauppinen, M.; Saikkonen, K.; Helander, M.; Pirttilä, A.M.; Wäli, P.R. Epichloë grass endophytes in sustainable agriculture. Nat. Plants 2016, 2, 1-7. [CrossRef]

55. Service, N.R.C.; Department, A. Keys to Soil Taxonomy; Government Printing Office: Washington, DC, USA, 2010.

56. Pacific Biosciences. Procedure E Checklist-Amplification of Full-Length $16 S$ Gene with Barcoded Primers for Multiplexed SMRTbell®Library Preparation and Sequencing; Pacific Biosciences: Menlo Park, CA, USA, 2018. Available online: https: //www.pacb.com/wp-content/uploads/Procedure-Checklist-\%E2\%80\%93-Amplification-of-Full-Length-16S-Gene-withBarcoded-Primers-for-Multiplexed-SMRTbell-Library-Preparation-and-Sequencing.pdf (accessed on 24 June 2021).

57. Callahan, B.J.; McMurdie, P.J.; Rosen, M.J.; Han, A.W.; Johnson, A.J.A.; Holmes, S.P. DADA2: High-resolution sample inference from Illumina amplicon data. Nat. Methods 2016, 13, 581-583. [CrossRef]

58. McMurdie, P.J.; Holmes, S. phyloseq: An R package for reproducible interactive analysis and graphics of microbiome census data. PLoS ONE 2013, 8, e61217. [CrossRef] [PubMed]

59. Erdem, E.; Erdogan, H.; Oztok, U. BIOQUERY-ASP: Querying biomedical ontologies using answer set programming. Proc. RuleML2011@BRF Chall. 2011, 573-578. [CrossRef]

60. Nilsson, R.H.; Larsson, K.-H.; Taylor, A.F.S.; Bengtsson-Palme, J.; Jeppesen, T.S.; Schigel, D.; Kennedy, P.; Picard, K.; Glöckner, F.O.; Tedersoo, L. The UNITE database for molecular identification of fungi: Handling dark taxa and parallel taxonomic classifications. Nucleic Acids Res. 2019, 47, D259-D264. [CrossRef] [PubMed]

61. Roberts, E.L.; Ferraro, A. Rhizosphere microbiome selection by Epichloë endophytes of Festuca arundinacea. Plant Soil 2015, 396, 229-239. [CrossRef]

62. Franzluebbers, A.; Nazih, N.; Stuedemann, J.; Fuhrmann, J.; Schomberg, H.; Hartel, P. Soil carbon and nitrogen pools under low-and high-endophyte-infected tall fescue. Soil Sci. Soc. Am. J. 1999, 63, 1687-1694. [CrossRef]

63. Franzluebbers, A.; Hill, N. Soil carbon, nitrogen, and ergot alkaloids with short-and long-term exposure to endophyte-infected and endophyte-free tall fescue. Soil Sci. Soc. Am. J. 2005, 69, 404-412. [CrossRef]

64. Franzluebbers, A.; Stuedemann, J. Soil carbon and nitrogen pools in response to tall fescue endophyte infection, fertilization, and cultivar. Soil Sci. Soc. Am. J. 2005, 69, 396-403. [CrossRef]

65. Van Hecke, M.M.; Treonis, A.M.; Kaufman, J.R. How does the fungal endophyte Neotyphodium coenophialum affect tall fescue (Festuca arundinacea) rhizodeposition and soil microorganisms? Plant Soil 2005, 275, 101-109. [CrossRef]

66. Vos, M.; Wolf, A.B.; Jennings, S.J.; Kowalchuk, G.A. Micro-scale determinants of bacterial diversity in soil. FEMS Microbiol. Rev. 2013, 37, 936-954. [CrossRef]

67. Urbanová, M.; Kopecký, J.; Valášková, V.; Ságová-Marečková, M.; Elhottová, D.; Kyselková, M.; Moënne-Loccoz, Y.; Baldrian, P. Development of bacterial community during spontaneous succession on spoil heaps after brown coal mining. FEMS Microbiol. Ecol. 2011, 78, 59-69. [CrossRef]

68. Urbanová, M.; Šnajdr, J.; Baldrian, P. Composition of fungal and bacterial communities in forest litter and soil is largely determined by dominant trees. Soil Biol. Biochem. 2015, 84, 53-64. [CrossRef]

69. Buckley, D.H.; Huangyutitham, V.; Nelson, T.A.; Rumberger, A.; Thies, J.E. Diversity of Planctomycetes in soil in relation to soil history and environmental heterogeneity. Appl. Environ. Microbiol. 2006, 72, 4522-4531. [CrossRef]

70. Chaudhry, V.; Rehman, A.; Mishra, A.; Chauhan, P.S.; Nautiyal, C.S. Changes in bacterial community structure of agricultural land due to long-term organic and chemical amendments. Microb. Ecol. 2012, 64, 450-460. [CrossRef] [PubMed]

71. Ditterich, F.; Poll, C.; Pronk, G.J.; Heister, K.; Chandran, A.; Rennert, T.; Kögel-Knabner, I.; Kandeler, E. Succession of soil microbial communities and enzyme activities in artificial soils. Pedobiologia 2016, 59, 93-104. [CrossRef]

72. Hartmann, M.; Frey, B.; Mayer, J.; Mäder, P.; Widmer, F. Distinct soil microbial diversity under long-term organic and conventional farming. ISME J. 2015, 9, 1177-1194. [CrossRef] [PubMed]

73. Lupatini, M.; Korthals, G.W.; de Hollander, M.; Janssens, T.K.; Kuramae, E.E. Soil microbiome is more heterogeneous in organic than in conventional farming system. Front. Microbiol. 2017, 7, 2064. [CrossRef]

74. Fierer, N.; Bradford, M.A.; Jackson, R.B. Toward an ecological classification of soil bacteria. Ecology 2007, 88, 1354-1364. [CrossRef]

75. Chen, Y.; Xin, L.; Liu, J.; Yuan, M.; Liu, S.; Jiang, W.; Chen, J. Changes in bacterial community of soil induced by long-term straw returning. Sci. Agric. 2017, 74, 349-356. [CrossRef]

76. Ramirez-Villanueva, D.A.; Bello-López, J.M.; Navarro-Noya, Y.E.; Luna-Guido, M.; Verhulst, N.; Govaerts, B.; Dendooven, L. Bacterial community structure in maize residue amended soil with contrasting management practices. Appl. Soil Ecol. 2015, 90, 49-59. [CrossRef] 
77. Mahmud, K.; Franklin, D.; Ney, L.; Cabrera, M.; Habteselassie, M.; Hancock, D.; Newcomer, Q.; Subedi, A.; Dahal, S. Improving inorganic nitrogen in soil and nutrient density of edamame bean in three consecutive summers by utilizing a locally sourced bio-inocula. Org. Agric. 2021, 11, 1-11. [CrossRef]

78. Lugtenberg, B.; Kamilova, F. Plant-growth-promoting rhizobacteria. Annu. Rev. Microbiol. 2009, 63, 541-556. [CrossRef]

79. Wang, Q.; Wang, C.; Yu, W.; Turak, A.; Chen, D.; Huang, Y.; Ao, J.; Jiang, Y.; Huang, Z. Effects of nitrogen and phosphorus inputs on soil bacterial abundance, diversity, and community composition in Chinese fir plantations. Front. Microbiol. $2018,9,1543$. [CrossRef] [PubMed]

80. Malinowski, D.P.; Belesky, D.P. Epichloë (formerly Neotyphodium) fungal endophytes increase adaptation of cool-season perennial grasses to environmental stresses. Acta Agrobot. 2019, 2, 72. [CrossRef]

81. Wang, J.; Hou, W.; Christensen, M.J.; Li, X.; Xia, C.; Li, C.; Nan, Z. Role of Epichloë endophytes in improving host grass resistance ability and soil properties. J. Agric. Food Chem. 2020, 68, 6944-6955. [CrossRef] [PubMed]

82. Malinowski, D.P.; Belesky, D.P. Adaptations of endophyte-infected cool-season grasses to environmental stresses: Mechanisms of drought and mineral stress tolerance. Crop Sci. 2000, 40, 923-940. [CrossRef]

83. Eilers, K.G.; Lauber, C.L.; Knight, R.; Fierer, N. Shifts in bacterial community structure associated with inputs of low molecular weight carbon compounds to soil. Soil Biol. Biochem. 2010, 42, 896-903. [CrossRef]

84. Joshi, S.; Jaggi, V.; Gangola, S.; Singh, A.; Sah, V.; Sahgal, M. Contrasting rhizosphere bacterial communities of healthy and wilted Dalbergia sissoo Roxb. forests. Rhizosphere 2021, 17, 100295. [CrossRef]

85. Waller, J.C. Endophyte effects on cattle. Tall Fescue Twenty-First Century 2009, 53, 289-310.

86. Fierer, N.; Ladau, J.; Clemente, J.C.; Leff, J.W.; Owens, S.M.; Pollard, K.S.; Knight, R.; Gilbert, J.A.; McCulley, R.L. Reconstructing the microbial diversity and function of pre-agricultural tallgrass prairie soils in the United States. Science 2013, 342, 621-624. [CrossRef]

87. Trivedi, P.; Anderson, I.C.; Singh, B.K. Microbial modulators of soil carbon storage: Integrating genomic and metabolic knowledge for global prediction. Trends Microbiol. 2013, 21, 641-651. [CrossRef]

88. Ding, J.; Jiang, X.; Guan, D.; Zhao, B.; Ma, M.; Zhou, B.; Cao, F.; Yang, X.; Li, L.; Li, J. Influence of inorganic fertilizer and organic manure application on fungal communities in a long-term field experiment of Chinese Mollisols. Appl. Soil Ecol. 2017, 111, 114-122. [CrossRef]

89. Mueller, R.C.; Paula, F.S.; Mirza, B.S.; Rodrigues, J.L.; Nüsslein, K.; Bohannan, B.J. Links between plant and fungal communities across a deforestation chronosequence in the Amazon rainforest. ISME J. 2014, 8, 1548-1550. [CrossRef]

90. Sun, R.; Dsouza, M.; Gilbert, J.A.; Guo, X.; Wang, D.; Guo, Z.; Ni, Y.; Chu, H. Fungal community composition in soils subjected to long-term chemical fertilization is most influenced by the type of organic matter. Environ. Microbiol. 2016, 18, 5137-5150. [CrossRef]

91. Hiscox, J.; Savoury, M.; Müller, C.T.; Lindahl, B.D.; Rogers, H.J.; Boddy, L. Priority effects during fungal community establishment in beech wood. ISME J. 2015, 9, 2246-2260. [CrossRef] [PubMed]

92. Kivlin, S.N.; Winston, G.C.; Goulden, M.L.; Treseder, K.K. Environmental filtering affects soil fungal community composition more than dispersal limitation at regional scales. Fungal Ecol. 2014, 12, 14-25. [CrossRef]

93. Yao, Q.; Liu, J.; Yu, Z.; Li, Y.; Jin, J.; Liu, X.; Wang, G. Changes of bacterial community compositions after three years of biochar application in a black soil of northeast China. Appl. Soil Ecol. 2017, 113, 11-21. [CrossRef]

94. Ponge, J.-F. Plant-soil feedbacks mediated by humus forms: A review. Soil Biol. Biochem. 2013, 57, 1048-1060. [CrossRef]

95. Requena, N.; Jimenez, I.; Toro, M.; Barea, J. Interactions between plant-growth-promoting rhizobacteria (PGPR), arbuscular mycorrhizal fungi and Rhizobium spp. in the rhizosphere of Anthyllis cytisoides, a model legume for revegetation in mediterranean semi-arid ecosystems. New Phytol. 1997, 136, 667-677. [CrossRef] [PubMed]

96. Sláviková, E.; Košíková, B.; Mikulášová, M. Biotransformation of waste lignin products by the soil-inhabiting yeast Trichosporon pullulans. Can. J. Microbiol. 2002, 48, 200-203. [CrossRef]

97. Van Bruggen, A.H.; Semenov, A.M. In search of biological indicators for soil health and disease suppression. Appl. Soil Ecol. 2000, 15, 13-24. [CrossRef]

98. Vázquez, M.M.; César, S.; Azcón, R.; Barea, J.M. Interactions between arbuscular mycorrhizal fungi and other microbial inoculants (Azospirillum, Pseudomonas, Trichoderma) and their effects on microbial population and enzyme activities in the rhizosphere of maize plants. Appl. Soil Ecol. 2000, 15, 261-272. [CrossRef]

99. Rousk, J.; Bååth, E.; Brookes, P.C.; Lauber, C.L.; Lozupone, C.; Caporaso, J.G.; Knight, R.; Fierer, N. Soil bacterial and fungal communities across a pH gradient in an arable soil. ISME J. 2010, 4, 1340-1351. [CrossRef] [PubMed]

100. Van Der Heijden, M.G.; De Bruin, S.; Luckerhoff, L.; Van Logtestijn, R.S.; Schlaeppi, K. A widespread plant-fungal-bacterial symbiosis promotes plant biodiversity, plant nutrition and seedling recruitment. ISME J. 2016, 10, 389-399. [CrossRef] [PubMed]

101. Nissinen, R.; Helander, M.; Kumar, M.; Saikkonen, K. Heritable Epichloë symbiosis shapes fungal but not bacterial communities of plant leaves. Sci. Rep. 2019, 9, 5253. [CrossRef] [PubMed]

102. Dix, N.J. Fungal Ecology; Springer Science \& Business Media: Berlin/Heidelberg, Germany, 2012.

103. Guo, J.; McCulley, R.; Phillips, T.; McNear, D., Jr. Fungal endophyte and tall fescue cultivar interact to differentially affect bulk and rhizosphere soil processes governing C and N cycling. Soil Biol. Biochem. 2016, 101, 165-174. [CrossRef]

104. Lugtenberg, B.J.; Caradus, J.R.; Johnson, L.J. Fungal endophytes for sustainable crop production. FEMS Microbiol. Ecol. 2016, 92, fiw194. [CrossRef] 
105. Rostás, M.; Cripps, M.G.; Silcock, P. Aboveground endophyte affects root volatile emission and host plant selection of a belowground insect. Oecologia 2015, 177, 487-497. [CrossRef] [PubMed]

106. Rasmussen, S.; Parsons, A.J.; Fraser, K.; Xue, H.; Newman, J.A. Metabolic profiles of Lolium perenne are differentially affected by nitrogen supply, carbohydrate content, and fungal endophyte infection. Plant Physiol. 2008, 146, 1440-1453. [CrossRef] [PubMed]

107. Guo, J.; McCulley, R.L.; McNear, D.H., Jr. Tall fescue cultivar and fungal endophyte combinations influence plant growth and root exudate composition. Front. Plant Sci. 2015, 6, 183. [CrossRef] [PubMed]

108. Rojas, X.; Guo, J.; Leff, J.W.; McNear, D.H.; Fierer, N.; McCulley, R.L. Infection with a shoot-specific fungal endophyte (Epichloë) alters tall fescue soil microbial communities. Microb. Ecol. 2016, 72, 197-206. [CrossRef]

109. Ding, N.; Guo, H.; Kupper, J.V.; McNear, D.H., Jr. Phosphorus source and Epichloë coenophiala strain interact over time to modify tall fescue rhizosphere microbial community structure and function. Soil Biol. Biochem. 2021, 154, 108125. [CrossRef]

110. Tedersoo, L.; Bahram, M.; Põlme, S.; Kõljalg, U.; Yorou, N.S.; Wijesundera, R.; Ruiz, L.V.; Vasco-Palacios, A.M.; Thu, P.Q.; Suija, A. Global diversity and geography of soil fungi. Science 2014, 346, 1256688. [CrossRef]

111. García-García, N.; Tamames, J.; Linz, A.M.; Pedrós-Alió, C.; Puente-Sánchez, F. Microdiversity ensures the maintenance of functional microbial communities under changing environmental conditions. ISME J. 2019, 13, 2969-2983. [CrossRef] [PubMed]

112. Griffiths, B.S.; Philippot, L. Insights into the resistance and resilience of the soil microbial community. FEMS Microbiol. Rev. 2013, 37, 112-129. [CrossRef]

113. Erkus, O.; De Jager, V.C.; Spus, M.; van Alen-Boerrigter, I.J.; Van Rijswijck, I.M.; Hazelwood, L.; Janssen, P.W.; Van Hijum, S.A.; Kleerebezem, M.; Smid, E.J. Multifactorial diversity sustains microbial community stability. ISME J. 2013, 7, 2126-2136. [CrossRef] [PubMed]

114. Shade, A.; Read, J.S.; Youngblut, N.D.; Fierer, N.; Knight, R.; Kratz, T.K.; Lottig, N.R.; Roden, E.E.; Stanley, E.H.; Stombaugh, J. Lake microbial communities are resilient after a whole-ecosystem disturbance. ISME J. 2012, 6, 2153-2167. [CrossRef] [PubMed]

115. Rho, H.; Hsieh, M.; Kandel, S.L.; Cantillo, J.; Doty, S.L.; Kim, S.-H. Do endophytes promote growth of host plants under stress? A meta-analysis on plant stress mitigation by endophytes. Microb. Ecol. 2018, 75, 407-418. [CrossRef] [PubMed]

116. Taylor, B.N.; Menge, D.N. Light regulates tropical symbiotic nitrogen fixation more strongly than soil nitrogen. Nat. Plants 2018, 4, 655-661. [CrossRef]

117. Kaschuk, G.; Kuyper, T.W.; Leffelaar, P.A.; Hungria, M.; Giller, K.E. Are the rates of photosynthesis stimulated by the carbon sink strength of rhizobial and arbuscular mycorrhizal symbioses? Soil Biol. Biochem. 2009, 41, 1233-1244. [CrossRef]

118. Van Der Putten, W.H. Belowground drivers of plant diversity. Science 2017, 355, 134-135. [CrossRef]

119. Bever, J.D.; Platt, T.G.; Morton, E.R. Microbial population and community dynamics on plant roots and their feedbacks on plant communities. Annu. Rev. Microbiol. 2012, 66, 265-283. [CrossRef]

120. Lekberg, Y.; Bever, J.D.; Bunn, R.A.; Callaway, R.M.; Hart, M.M.; Kivlin, S.N.; Klironomos, J.; Larkin, B.G.; Maron, J.L.; Reinhart, K.O. Relative importance of competition and plant-soil feedback, their synergy, context dependency and implications for coexistence. Ecol. Lett. 2018, 21, 1268-1281. [CrossRef] [PubMed]

121. Yu, J.; Whalen, J.K. A new perspective on functional redundancy and phylogenetic niche conservatism in soil microbial communities. Pedosphere 2020, 30, 18-24. 